\title{
Epidemiology of ovarian malignancies
}

\author{
Akanksha Sood*, Rekha G. Daver, Sanjay G. Tambe
}

Department of Obstetrics and Gynaecology, Grant Medical College and J.J. Group of Hospitals, Mumbai, Maharashtra, India

Received: 10 October 2015

Revised: 18 October 2015

Accepted: 14 December 2015

\section{*Correspondence:}

Dr. Akanksha Sood,

E-mail: drakankshasood@gmail.com

Copyright: ( $\odot$ the author(s), publisher and licensee Medip Academy. This is an open-access article distributed under the terms of the Creative Commons Attribution Non-Commercial License, which permits unrestricted non-commercial use, distribution, and reproduction in any medium, provided the original work is properly cited.

\section{ABSTRACT}

Background: The location of the ovaries makes it difficult to diagnose ovarian cancer at an earlier more curable stage. This study was done with intend of developing insight into risk factors, clinical presentation and prognostic factors for the same.

Methods: An observational prospective study was undertaken over a period of 2 years of 77 cases in a tertiary care hospital with cancer unit. Case records of cases during study period were evaluted and epidemiology studied.

Results: Most of the malignant tumors i.e. $35.1 \%$ were in the age group of $40-50 \mathrm{yrs}$ and $42 \%$ of tumors seen in the age group of 41-60 years. $9.1 \%$ were post hysterectomy, $46.8 \%$ were premenopausal and $44.2 \%$ were postmenstrual. Majority cases were parous women and none had used oral contraceptive pills. In the present study, blood group A was found more commonly more commonly associated with ovarian tumors in comparison to the general population. the most common complaint of the patient was pain in abdomen (70.1\%) followed by distension of abdomen (45.5\%) and menstrual irregularities (16.9\%).

Conclusions: The epidemiology and presentation of ovarian tumours has remained unchanged since last 3 decades. Nulliparity is not as significant a factor in the aetiology of ovarian malignancy however contraception leading to anovulatory cycles (OC pills) may have a protective role. Infertility can be suggested as a risk factor but the treatment for infertility \& its role in oncogenesis remains controversial.

Keywords: Ovarian Malignancies, Ovarian tumours, Epidemiology

\section{INTRODUCTION}

Howard Taylor once said "Ovarian malignancy is a group of disease and not a single one". The tremendous diversity of malignancies associated with the ovary makes it a difficult subject to study. Because of the location of the ovaries, it is difficult to diagnose ovarian cancer at an earlier more curable stage. Ovarian cancer does not cause any specific signs or symptoms until late, when it metastasises. Symptoms suggestive of ovarian cancer include bloating, pelvic/ abdominal pain, difficulty in eating or feeling full quickly and urinary symptoms (urgency/frequency).Till date no screening strategy has been found to be effective in the early diagnosis of the disease with resultant reduction of mortality. This study was done with intend of developing insight into risk factors, clinical presentation and prognostic factors for the same.

The objective of the study was

1 To study the the epidemiological factors of $\mathrm{Ca}$ ovary. 
2 To study various clinical presentations / stage of presentation of Ca ovary.

3 To study the contributory factors and identify prognostic factors ( if any )
a. Age.
b. Parity.
c. Ethnicity.
d. Use of oral contraceptive pills, e.t.c.

\section{METHODS}

The present study of ovarian tumors was undertaken in Cama Albless Hospital, Mumbai, a tertiary hospital with cancer unit for a period of 2 years. This was a observational prospective study of 77 cases after ethical comittee clearance and consent from each patient who participated in the study.

\section{Inclusion criteria}

Patients with proven histopathological diagnosis or cytological diagnosis of ovarian cancer of all age group were included in this study. Cases of adnexal mass with doubtful diagnosis were excluded.

A detailed history was elicited, thorough clinical (general,systemic and pelvic) examination done and clinical diagnosis was put forward. The clinical diagnosis was corroborated with the diagnosis put forth by USG ( transabdominal/transvaginal), CT/MRI, serological markers and impression of FNAC (USG guided),fluid cytology. Histopathological diagnosis was taken as the "gold standard" for final diagnosis.

Case records of cases during study period were evaluted and epidemiology studied.

\section{RESULTS}

The present study is an observational prospective study of 77 cases of ovarian malignancy over a period of 2 years. The following results were obtained.

Table 1: Age distribution of ovarian tumors ( $N=77)$.

\begin{tabular}{|lll|}
\hline A GE (years) & No. of cases & $\%$ \\
\hline 10 to 20 & 4 & 5.2 \\
\hline 20 to 30 & 12 & 15.6 \\
\hline 30 to 40 & 12 & 15.6 \\
\hline 40 to 50 & 27 & 35.1 \\
\hline 50 to 60 & 13 & 16.9 \\
\hline$>60$ & 9 & 11.7 \\
\hline Total & 77 & \\
\hline
\end{tabular}

Mean age: 45.18 years
Malignancy is more commly seen with increasing age. Most of the malignant tumors i.e. $35.1 \%$ (27 cases) were in the age group of 40- 50 yrs and $42 \%$ of tumors(40 cases) seen in the age group of 41-60 years.

Youngest patient with malignant ovarian tumor was at age of 13 years. i.e. dysgerminoma. Oldest patient with malignant ovarian tumor was 75 years of age with adenocarcinoma.

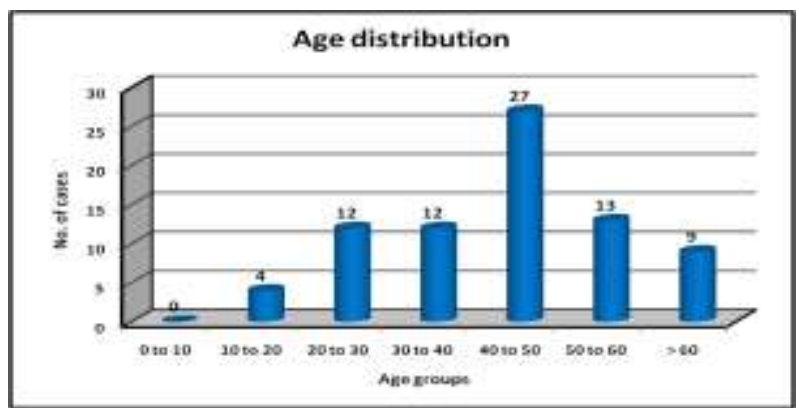

Figure 1(a): Age distribution of ovarian tumors $(\mathrm{N}=77)$.

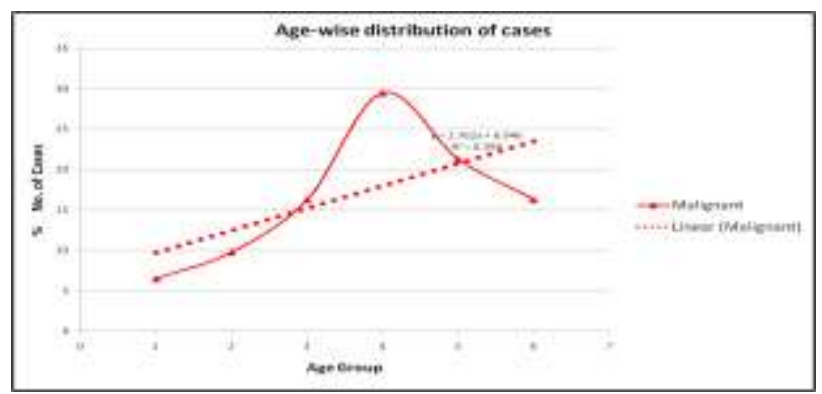

Figure 1(b): Age distribution of ovarian tumors ( $N=77)$.

Table 2: Religion distribution $(\mathrm{N}=77)$.

\begin{tabular}{|lll|}
\hline Religion & No. of cases & $\%$ \\
\hline Hindu & 59 & 76.6 \\
\hline Muslim & 16 & 20.8 \\
\hline Christian & 2 & 2.6 \\
\hline Total & $\mathbf{7 7}$ & \\
\hline
\end{tabular}

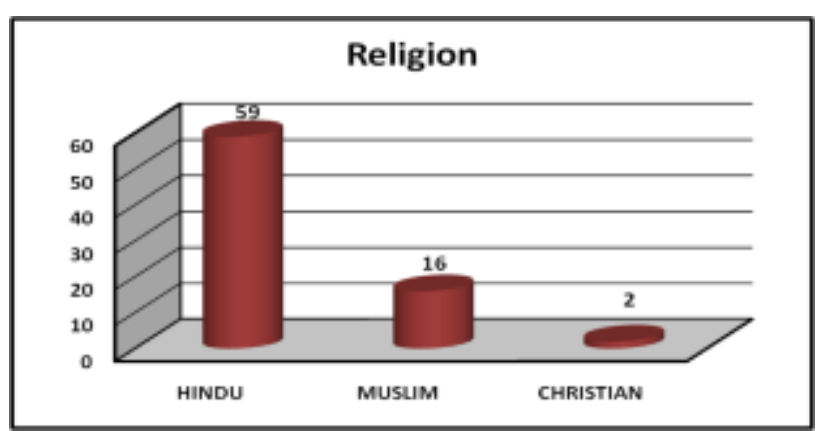

Figure 2: Religion distribution $(\mathrm{N}=77)$. 
In the present study, $76.62 \%$ (59 cases) were Hindus.

Table 3: Occupation distribution $(\mathrm{N}=77)$.

\begin{tabular}{|lll|}
\hline Occupation & No. of cases & $\%$ \\
\hline Housewife & 69 & 89.6 \\
\hline Student & 4 & 5.2 \\
\hline Govt. Servant & 2 & 2.6 \\
\hline Daily wages & 2 & 2.6 \\
\hline Total & $\mathbf{7 7}$ & \\
\hline
\end{tabular}

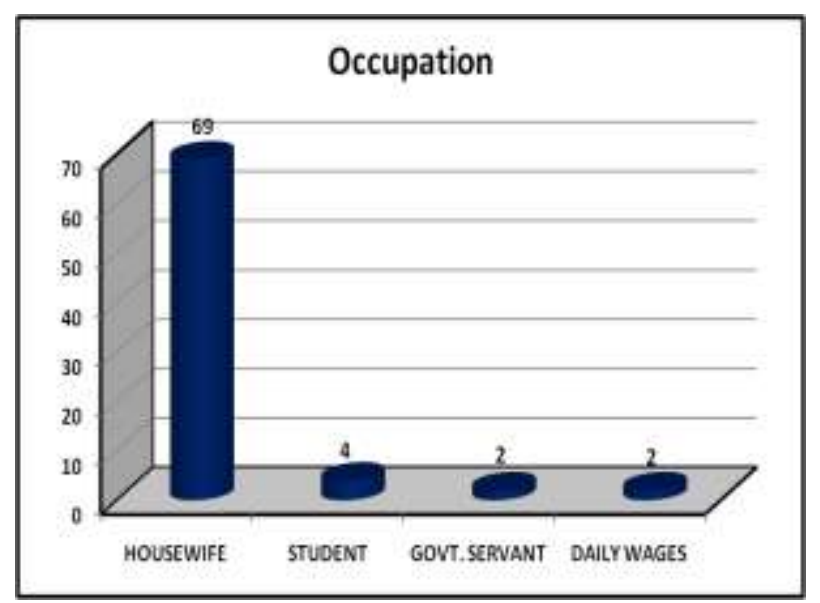

Figure 3: Occupation distribution $(\mathrm{N}=77)$.

Most of the cases $(89.6 \%$; 69 cases) were unemployed/housewives.

Table 4: Menstrual status $(\mathrm{N}=77)$.

\begin{tabular}{|lll|}
\hline Menstrual status & No. of cases & $\%$ \\
\hline Premenopausal & 36 & 46.8 \\
\hline Postmenopausal & 34 & 44.2 \\
\hline $\begin{array}{l}\text { Post hysterectomy (Surgical } \\
\text { menopause) }\end{array}$ & 7 & 9.1 \\
\hline Total & $\mathbf{7 7}$ & \\
\hline
\end{tabular}

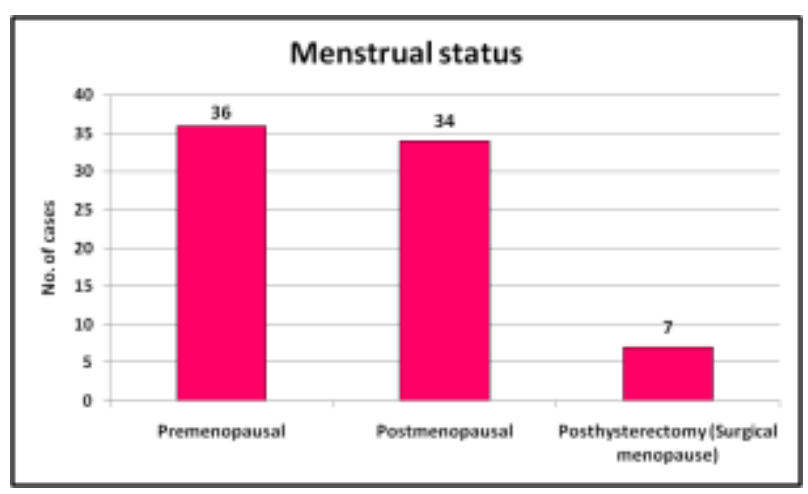

Figure 4: Menstrual status $(\mathrm{N}=77)$.

$9.1 \%$ ( 7 cases) were post hysterectomy, $46.8 \%$ (36 cases) were premenopausal and 44.2\% (34 cases) were postmenstrual.

Table 5: Parity distribution of ovarian tumors $(\mathrm{N}=77)$.

\begin{tabular}{|lll|}
\hline Parity & No. of cases & $\%$ \\
\hline Nullipara & 14 & 18.2 \\
\hline Para 1 & 6 & 7.8 \\
\hline Para 2 & 21 & 27.3 \\
\hline Para 3 & 17 & 22.1 \\
\hline Para 4 & 8 & 10.4 \\
\hline Para 5 \& above & 11 & 14.3 \\
\hline Total & $\mathbf{7 7}$ & \\
\hline
\end{tabular}

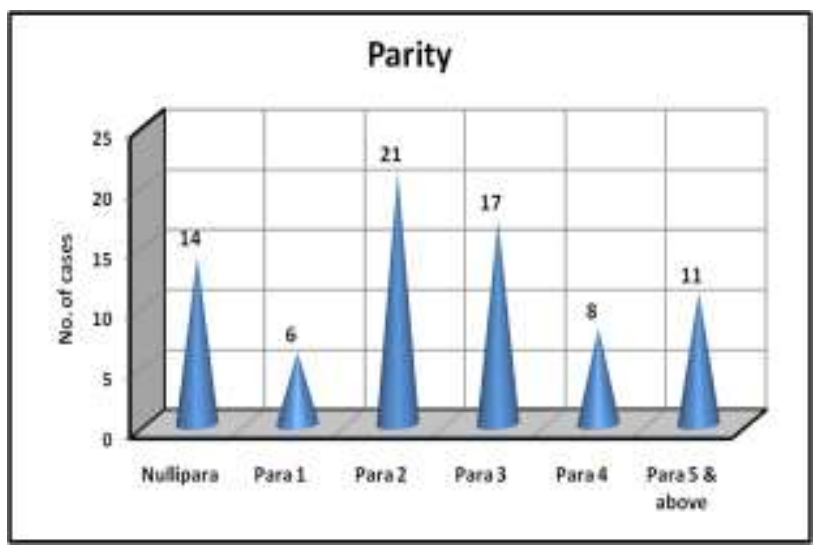

Figure 5(a): Parity distribution of ovarian tumors $(\mathrm{N}=77)$.

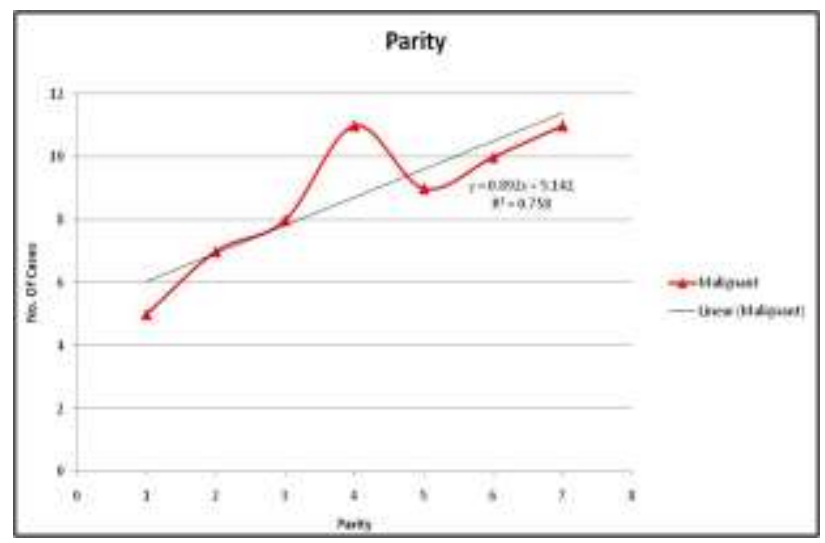

Figure 5(b): Parity distribution of ovarian tumors $(\mathrm{N}=77)$.

In present study $18.2 \%$ (14 cases) were nulliparous and $7.8 \%$ (6 cases) were para 1.

Table 6: Contraception ( $\mathrm{N}=77)$.

\begin{tabular}{|lll|}
\hline Contraception & No. of cases & $\%$ \\
\hline Tubal ligation & 19 & 25 \\
\hline No contraception & 58 & 75 \\
\hline Total & $\mathbf{7 7}$ & \\
\hline
\end{tabular}




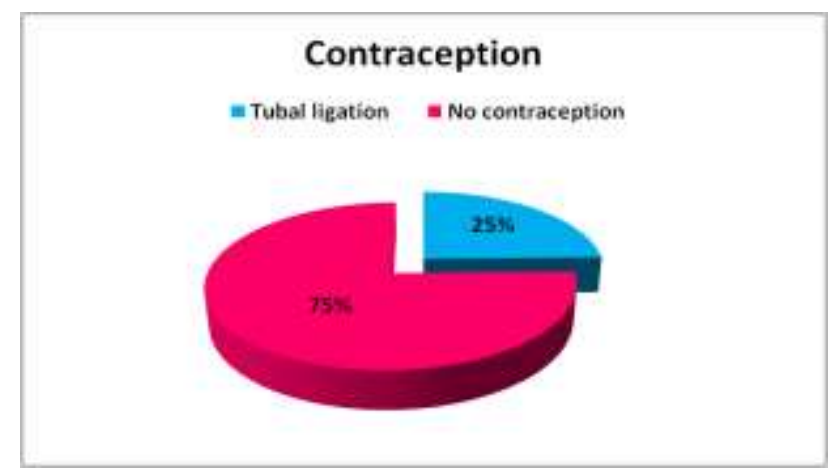

Figure 6 (a): Contraception $(\mathrm{N}=77)$.

$25 \%$ (19 cases) had undergone tubal ligation, $75 \%$ (58 cases) had not used any form of contraception in their life. None of the cases had taken oral contraceptive pills.

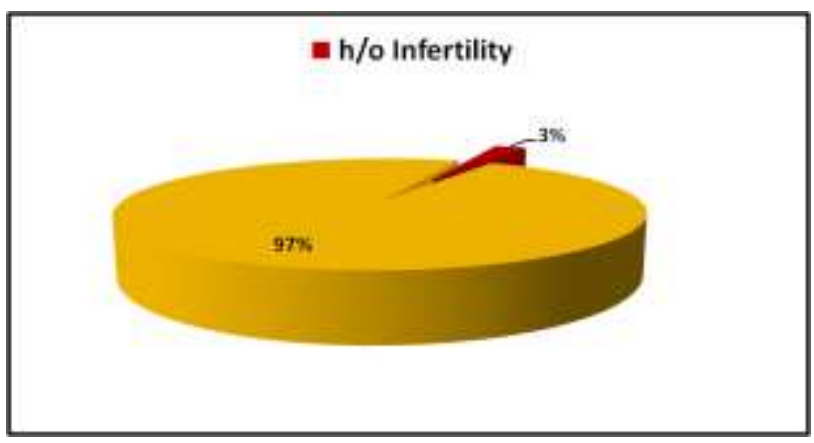

Figure 6 (b): Infertility (N=77).

$3 \%$ of cases in the study had history of infertility.

Table 7(a): Blood group distribution $(\mathrm{N}=77)$.

\begin{tabular}{|lll|}
\hline Blood Group & No. of cases & $\%$ \\
\hline A Positive & 27 & 35.1 \\
\hline B Positive & 17 & 22.1 \\
\hline AB Positive & 6 & 7.8 \\
\hline O Positive & 26 & 33.8 \\
\hline A Negative & 0 & 0 \\
\hline B Negative & 1 & 1.3 \\
\hline AB Negative & 0 & 0 \\
\hline O Negative & 0 & 0 \\
\hline Total & 77 & \\
\hline
\end{tabular}

Table 7(b): Blood group distribution $(\mathrm{N}=77)$.

\begin{tabular}{|llll|}
\hline $\begin{array}{l}\text { Blood } \\
\text { Group }\end{array}$ & $\begin{array}{l}\text { Present } \\
\text { study }(\%)\end{array}$ & $\begin{array}{l}\text { Normal } \\
\text { population (\%) }\end{array}$ & 'P' \\
\hline A & 35.1 & 22 & $<0.01$ \\
\hline B & 23.4 & 33 & $0.55(\mathrm{NS})$ \\
\hline AB & 7.8 & 7 & $0.48(\mathrm{NS})$ \\
\hline O & 33.8 & 37 & $0.52(\mathrm{NS})$ \\
\hline
\end{tabular}

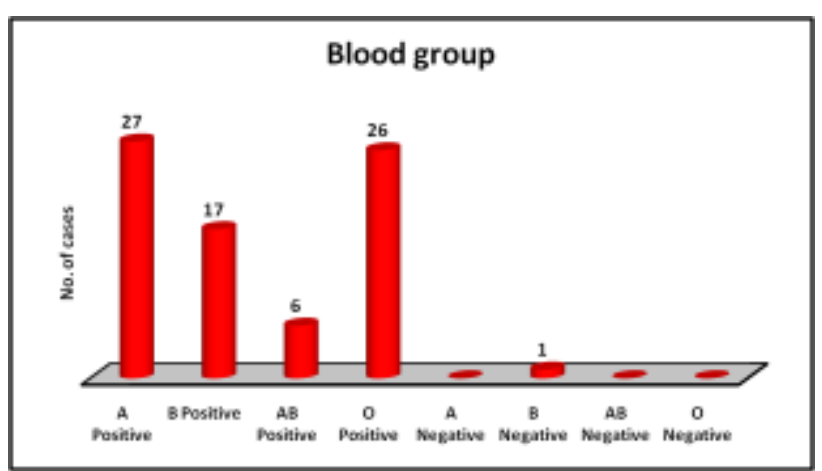

Figure 7: Blood group distribution $(\mathrm{N}=77)$.

Table 8: Presenting symptom $(\mathrm{N}=77)$.

\begin{tabular}{|lll|}
\hline Symptom & No. of cases & $\%$ \\
\hline Pain in abdomen & 54 & 70.1 \\
\hline Distension of abdomen & 35 & 45.5 \\
\hline Lump abdomen & 6 & 7.8 \\
\hline Menstrual irregularities & 13 & 16.9 \\
\hline Urinary complaints & 4 & 5.2 \\
\hline Bowel complaints & 3 & 3.9 \\
\hline PV Discharge & 3 & 3.9 \\
\hline Weight loss & 3 & 3.9 \\
\hline Lump in breast & 1 & 1.3 \\
\hline Inguinal swelling & 1 & 1.3 \\
\hline Post menopausal bleeding & 1 & 1.3 \\
\hline
\end{tabular}

Table 9: Duration of symptoms $(\mathrm{N}=77)$.

\begin{tabular}{|lll|}
\hline Duration of symptoms & No. of cases & $\%$ \\
\hline$<1$ month & 4 & 5.2 \\
\hline 1 month & 13 & 16.9 \\
\hline 2 months & 18 & 23.4 \\
\hline $3-6$ months & 15 & 19.5 \\
\hline $6-12$ months & 12 & 15.6 \\
\hline$>12$ months & 8 & 10.4 \\
\hline Total & 77 & \\
\hline
\end{tabular}

Table 10: Stage at presentation $(\mathrm{N}=77)$.

\begin{tabular}{|lll|}
\hline Clinical Staging & No. of cases & $\%$ \\
\hline Stage 1 & 26 & 33.8 \\
\hline Stage 2 & 7 & 9.1 \\
\hline Stage 3 & 25 & 32.5 \\
\hline Stage 4 & 19 & 24.7 \\
\hline Total & 77 & \\
\hline
\end{tabular}

In present study, maximum ovarian tumors cases $35.1 \%$ (27 cases) had blood group A positive (Table 7(a)).

In the present study, blood group A was found more commonly more commonly associated with ovarian tumors in comparison to the general population. 
In present study, the most common complaint of the patient was pain in abdomen $70.1 \%$ (54 cases) followed by distension of abdomen $45.5 \%$ (35 cases) and menstrual irregularities 16.9\% (13 cases) (Table 8, Figure 8).

In our study, $45.5 \%$ (35 cases) had vague complaints for $>3$ months and $10.8 \%$ ( 8 cases) had complaints > 12 months which were not recognized (Table 9, Figure 9).

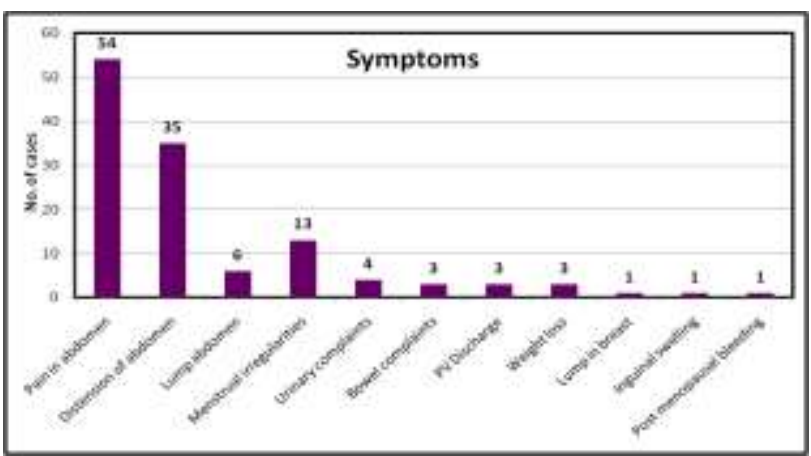

Figure 8: Presenting symptoms $(\mathrm{N}=77)$.

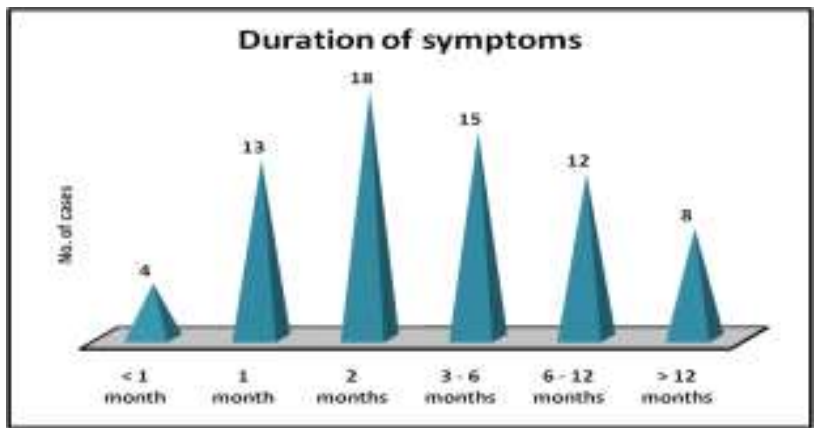

Figure 9: Duration of symptoms $(\mathrm{N}=77)$.

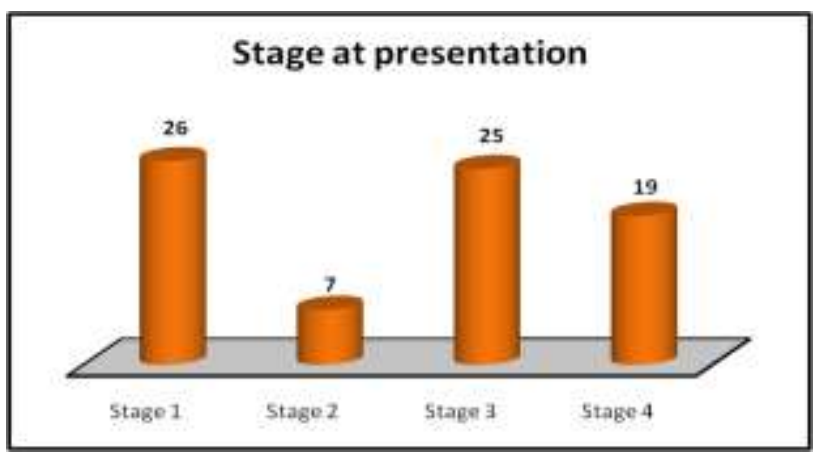

Figure 10: Stage at presentation $(\mathrm{N}=77)$.

The early symptoms of ovarian cancer are often over looked as digestive problems of middle aged woman. The frequent initial presenting complaints are abdominal discomfort, bloating sensation, early satiety and dyspepsia. Distension of abdomen, feeling of heaviness/mass in abdomen and pain occurs relatively late, when the mass exceeds $15 \mathrm{~cm}$ in size/ascitis appears. Often there is visible weight loss due to loss of appetite.
At an advanced stage patient may present with constipation due to intestinal obstruction or dyspnea due to pleural effusion. Due to the fact that ovarian cancers more often than not become symptomatic only when the disease becomes extra ovarian, in our study $57.2 \%$ (44 cases) presented in advanced stage (stage 3/4) (Table 10, Figure 10).

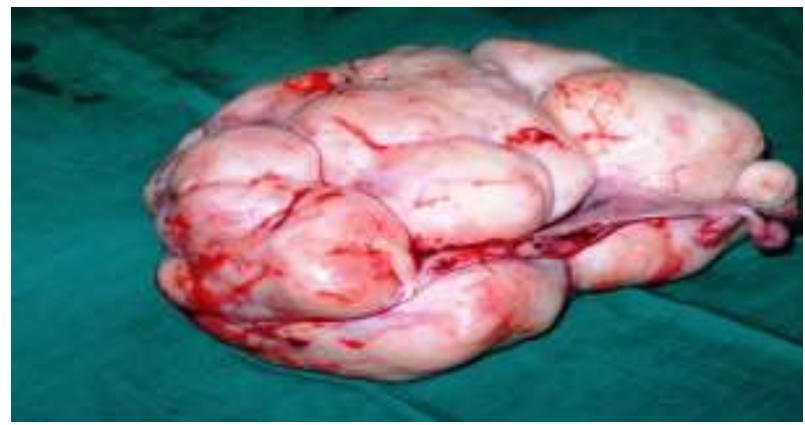

Figure 11: Serous cystadenocarcinoma.

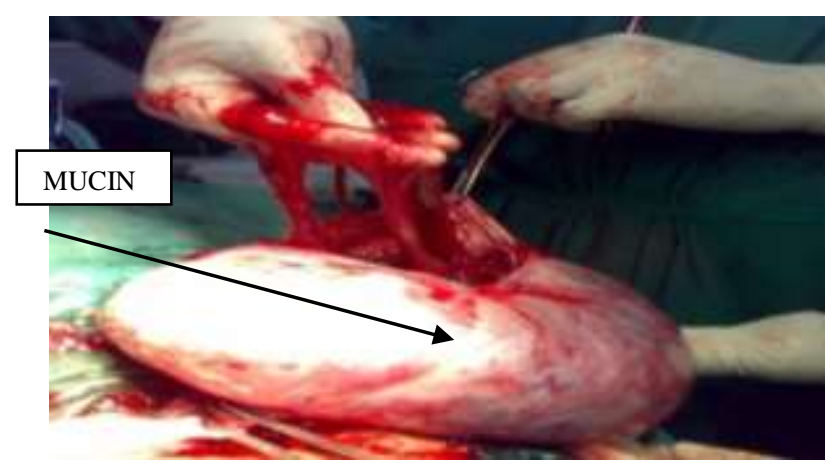

Figure 12: Mucinous cystadenocarcinoma.

\section{DISCUSSION}

Ovarian tumors are amongst the top five common tumors and second most common among gynecological malignancies among Indian women. It is a unrecognized threat to women's health. Its incidence is on the rise in countries like India. In Mumbai its incidence rate is 6.1 per 100,000 females with a truncated rate (age 35-64) of 14.2 per 100,000 females.

Ovarian carcinogenesis, as in most cancers involves multiple genetic alterations. A full understating of the earliest recognizable events in epithelial ovarian carcinogenesis is limited by the lack of a well-defined premalignant state common to all ovarian subtypes and by the paucity of data from early stage cancers.

\section{Age incidence}

Ovarian malignancies can occur at any age though the age range varies according to the histological types. Germ cell tumors are more common in $<20$ years of age whereas epithelial tumors are seen in women older than 
50 years. In our study the highest incidence was seen in age group 40-50 years. The mean age of the patients was 45.18 years (Table 1 , Figure $1 \mathrm{a}$ ).

Age per se, had no correlation to the development of an ovarian tumor. The youngest patient in our study was 13 years with dysgerminoma while oldest patient was 75 years with serous papillary adenocarcinoma. Our study correlated with most of the studies as compared in the table below:

Table 11: Age distribution in different studies.

\begin{tabular}{|lll|}
\hline Sr no & Study & Age (years) \\
\hline 1 & ${\text { Kurman RJ } 1994^{1}}^{1}$ & 50 \\
\hline 2 & ${\text { S Shah et al } 2006^{2}}^{2}$ & $>40$ \\
\hline 3 & ${\text { Rama Mani et al } 2007^{3}}^{3}$ & $>50$ \\
\hline 4 & Basu P et al 2008 $^{4}$ & $48.8+/-11.2$ \\
\hline 5 & Present study 2010 & $40-50$ \\
\hline
\end{tabular}

\section{Parity}

It has been shown that with each full ovulation year, a woman experiences $6 \%$ increase in risk of ovarian cancer. These findings are especially true in 20-29 years age group in which risk is highest, with $20 \%$ increase in risk with each ovulatory year a woman experiences. ${ }^{5}$

Out of the study $18.2 \%$ (14 cases) were nulliparous and $7.8 \%$ (6 cases) were para 1 (Table 5, Figure 5a).

National Survey of Ovarian Cancer, USA (1992) showed only $8.2 \%$ patients were Nulliparous. ${ }^{6}$

Shah et al observed ovarian tumours were more common in multiparous patients'. Only $18.6 \%$ of patients were nulligravida and $4 \%$ patients had tumor associated with pregnancy. $54 \%$ among benign and $75 \%$ among malignant tumours were multiparous. ${ }^{2}$

Fatima Zahra et al observed that out of 62 cases $16(26 \%)$ were Nulliparous and $46(74 \%)$ were multiparous. Among multiparous there were 27 cases $(44 \%)$ who had parity 1-4 and 19 cases (30\%) who had parity $>5$. Fatima Zahra et al observed that in patients with ovarian carcinoma maximum patient parity 3 and above. Hence nulliparity is not a significant factor in aetiology of both benign and malignant tumors. ${ }^{7}$

Hence, null parity was not found as a significant factor in aetiology of malignant tumours in our study (Figure 5b). Other protective factors for ovarian malignancy are tubal ligation and hysterectomy. These surgical procedures decrease risk of ovarian cancer by $30-40 \%{ }^{8}$ The postulated mechanism is prevention of preventing potential carcinogens from ascending to the ovary or reduced blood flow to the ovary. $75 \%$ of our patients used no contraception while $25 \%$ had undergone tubal ligation. (Table 6, Figure 6a).
None of our patients were found to have ever taken oral contraceptive pills. 9\% (7 cases) had undergone hysterectomy (Table 4, Figure 4).

Infertility also has been suggested as a risk factor for ovarian cancer but the treatment for infertility and its role in oncogenesis remains controversial. ${ }^{9}$ Numerous studies link endometriosis, a well-established cause of infertility, with an increased risk of ovarian cancer especially clear cell and Endometrioid subtype (39.2\% and 21.2\% respectively). ${ }^{10-13}$

The findings on ovarian cancer risk and its association with fertility drug treatment are not definitive and studies have not shown a direct correlation. ${ }^{14}$

In our study, 3\% of patients had infertility (Table 6b). Out of these, one case had history of ovulation induction (6 cycles).

Our study is correlated with other studies in the table below:

Table 12: Comparison of symptomatology in different studies ${ }^{19,20,2}$ :(Percentage of cases).

\begin{tabular}{|lllll|}
\hline Complaints & $\begin{array}{l}\text { Goff- } \\
\text { 2004 }\end{array}$ & $\begin{array}{l}\text { Olsen } \\
2001\end{array}$ & $\begin{array}{l}\text { S Shah } \\
2006\end{array}$ & $\begin{array}{l}\text { Present } \\
\text { study } \\
2010\end{array}$ \\
\hline $\begin{array}{l}\text { Distension } \\
\text { abdomen }\end{array}$ & 70 & & 31 & 45.5 \\
\hline $\begin{array}{l}\text { Lump } \\
\text { abdomen }\end{array}$ & 64 & 71 & 66 & 7.8 \\
\hline $\begin{array}{l}\text { Pain } \\
\text { abdomen }\end{array}$ & 50 & 52 & 100 & 70.1 \\
\hline $\begin{array}{l}\text { Menstrual } \\
\text { Complaints }\end{array}$ & - & - & - & 16.9 \\
\hline $\begin{array}{l}\text { Bladder } \\
\text { complaints }\end{array}$ & 55 & 33 & - & 5.2 \\
\hline $\begin{array}{l}\text { Bowel } \\
\text { complaints }\end{array}$ & - & 21 & - & 3.9 \\
\hline $\begin{array}{l}\text { White } \\
\text { Discharge }\end{array}$ & - & - & - & 3.9 \\
\hline Weight Loss & - & - & - & 3.9 \\
\hline Pelvic pain & 41 & - & - & - \\
\hline Fatigue & - & 43 & - & - \\
\hline Infertility & - & - & 8.6 & 3 \\
\hline
\end{tabular}

\section{Blood group}

In present study, maximum ovarian tumors cases $35.1 \%$ (27 cases) had blood group A positive (Table 7a, Figure $7)$.

In the present study, blood group A was found more commonly in comparison with general population (Table $7 b)$. 
Henderson $\mathbf{J}$, et al found that ovarian cancer was more common in women of blood group A than in others, with a relative incidence of 1.17. In particular; adenocarcinomas were the most common type of tumor and were associated with blood group A. The association was more striking in married women than in single women probably reflecting differences associated with parity.

Bjökholm E, Sweden also found that the disparity between the frequencies of blood groups $\mathrm{A}$ and $\mathrm{O}$ appeared to increase the risk of ovarian carcinoma by $19 \% .^{16}$

\section{Occupation}

89.6\% (69 cases) in our study were unemployed/ housewives (Table 3, Figure 3). No case had history of occupational exposure to talc, silica dust, aliphatic and aromatic hydrocarbons which have been suggested as risk factors in various studies. ${ }^{17,18}$

\section{Symptomatology}

It is a well known fact that ovarian tumors more often than not present with vague symptoms and that is the reason for their being diagnosed late.

\section{CONCLUSIONS}

Ovarian tumors are known to be enigmatic in behaviour, unclear in pathogenesis and controversial in terms of management. Further in terms of management, there are options of fertility conserving surgery in relatively younger women harbouring borderline tumors. Unlike invasive adenocarcinomas that are candidates for radical surgery with options of chemotherapy. Proper understanding of pathogenesis, complete investigation and thorough surgical staging are the cornerstones of management.

- The epidemiology and presentation of ovarian tumors has remained unchanged since last 3 decades.

- Malignancy is commoner with increasing age. However in first 2 decades germs cell tumour are common.

- Nulliparity is not as significant a factor in the etiology of ovarian malignancy however contraception leading to anovulatory cycles (OC pills) may have a protective role. Even tubal ligation could be having a protective role.

- Infertility can be suggested as a risk factor but the treatment for infertility \& its role in oncogenesis remains controversial

- Pain in abdomen is a common complaint in the varied and vague presentation of ovarian tumors Followed by distention of abdomen and menstrual irregularity.
- The early symptoms of ovarian tumors are often overlooked as "digestive problems" of a middle aged woman. Most women who complain of these symptoms will not have ovarian cancer. However, recognizing that the new onset or increased severity of these symptoms in collaboration with ultrasonography especially T.V.S. provides an important diagnostic opportunity.

Funding: No funding sources

Conflict of interest: None declared

Ethical approval: The study was approved by the Institutional Ethics Committee

\section{REFERENCES}

1. Seidman JD, Kurman RJ. Sub classification of serous borderline tumours of the ovary into benign and malignant types: a clinicopathologic study of 65 advanced stage cases. Am J Clin Oncol. 1995;13:2752-6.

2. S Shah. Incidence and Management of Ovarian Tumours. Bombay Hospital Journal. 2008;50(1).

3. Mani R, Jamil K, Vamsy MC. Trends in medical research. 2007;2(3):128-34.

4. Basu P. personal communication from a pattern of care study on ovarian cancer patients. 2008.

5. Purdie DM, Bain CJ, Siskind V. Ovulation and risk of epithelial ovarian cancer. Int $\mathrm{J}$ Cancer. 2003;104:228-32.

6. Averette HE, Hoskins W, Nguyen HN. National survey of ovarian carcinoma. I. A Patient care evaluation study of the American College of Surgeons. Cancer. 1993;71:1629.

7. Fatimah Zahra. Parity and epithelial ovarian tumours. Pak J Med Health Sci. 2007;1(1):45-8.

8. Jekyll JF, Katz DL. Elmore JG, Wild DM. Epidemiology, Biostatistics, and Preventive Medicine. Philadelphia: Saunders. 2007.

9. Meirow D, Schenker JG. The link between female infertility and cancer: epidemiology and possible actiologies. Hum Reprod update. 1996;2(1):63-75.

10. Ness RB, Cottreau C. Possible role of ovarian epithelial inflammation in ovarian cancer. J Natl Cancer Inst. 1999;91(17):1459-67.

11. Ness RB, Grisso JA, Cottreau C et al. Factors related to inflammation of the ovarian epithelium and risk of ovarian cancer. Epidemiology. 2000;11:111.

12. Ness RB. Endometriosis and ovarian cancer: thoughts on shared pathophysiology. Am J Obst Gyn. 2003;189(1):280-94.

13. Yoshikawa H, Jimbo H, Okala S. Prevalence of endometriosis in ovarian cancer. Gyn Obs Invest. 2000;50(1):11-7.

14. Mahdavi A, Pejovic T, Nerhot F. Induction of ovulation and ovarian cancer: a critical review of the literature. Ferti Steril. 2006;85(4):819-26.

15. Henderson J, Seagroatt V, Goldacre M. Ovarian cancer and $\mathrm{ABO}$ blood groups. J Epidemiol Community Health. 1993;47(4):287-9. 
16. Bjökholm E. Blood group distribution in women with ovarian cancer. International Journal of Epidemiology. 1984;13:15-17.

17. Wernli KJ, Ray RM. Occupational exposures and ovarian cancer in textile workers. Epidemiology Cambridge Mass. 2000;19,(2):244-50.

18. Sheilds T, Gridley G. Occupational exposures and the risk of ovarian cancer in Sweden. American journal of Industrial Medicine. 2002;42,(3):200-13.
19. Goff BA, Mandel LS, Melancon CH, Muntz HG. Frequency of symptoms of ovarian cancer in women presenting to primary care clinics. JAMA. 2004;291:2705-12.

20. Olsen SH, Mignone L, Nakraseive C. Symptoms of ovarian cancer. Obstetric Gynecol. 2001;98(2):2127.

Cite this article as: Sood A, Daver RG, Tambe SG. Epidemiology of ovarian malignancies. Int J Reprod Contracept Obstet Gynecol 2016;5:186-93. 